\title{
The Effects of Ten Weekly Plyometric Training of Judokas on Anaerobic Power
}

\author{
Ahmet Uzun ${ }^{1}$, Onder Karakoc ${ }^{1}$ \\ ${ }^{1}$ School of Physical Education and Sport, Gaziantep University, Turkey \\ Correspondence: Onder Karakoc, School of Physical Education and Sport, Gaziantep University, Turkey.
}

Received: December 19, 2017

Accepted: December 28, 2017

Online Published: December 29, 2017

doi:10.11114/jets.v5i13.2902

URL: https://doi.org/10.11114/jets.v5i13.2902

\begin{abstract}
This study was conducted to determine the effects of ten weekly plyometric training on anaerobic power in judokas. 30 male judokas participated in the study and the subjects were divided into two groups as an experimental ( 15 male age $=$ $21,40 \pm 1,99)$ and control $(15$ male age $=21,53 \pm 1,80)$ groups. Judo training programme was applied in both groups for 3 days / 90 minutes per week. Experimental and control group were made warm up exercises for 20 minutes. Both groups continued with the special preparatory period judo training program. After warm up exercises, experimental group judokas were made plyometric training consisting of 15 different movements for 20 minutes. Then they were allowed to continue the judo training. As the groups showed normal distribution, Paired Samples T-Test was applied for the significance between pre-test and post-test measurements of the groups. Independent Samples T-Test was used to analyze the difference between the test group and control group. The Independent Samples T-Test was used to analyze the difference between the experimental group and the control group. As a result of the plyometric training, when the pre-test and post-test differences of the physical measurement parameters for the experimental and control groups were compared, the mean values of back strength, anaerobic power and body fat percentage were found to be significant $(\mathrm{p}<0.05)$. However, there was no significance in the mean values of right hand grip strength, left hand grip strength, leg strength and flexibility( $\mathrm{p}>0.05)$.
\end{abstract}

As a result, it is seen that the regular plyometric exercises increase the performance of anaerobic power to judokas. It can be said that putting plyometric training besides judo training has a positive effect for performance.

Keywords: Judo, plyometric training, anaerobic power

\section{Introduction}

Physical suitability is required to produce a good performance on the Sport. In order to achieve high performance of sportive performance, physical and physiological structure must be appropriate specific to sports (Kalyon T. A. 1990). In researches on strength; the relation with strength to sportive performance, the relation with strength to other motoric properties and the effect of the applied different strength training models on the strength development are seen. In strength trainings, plyometric exercises are the most commonly used training models in recent years.

The work capacity arising from the use of anaerobic energy transfer systems of skeletal muscles during supramaximal and maximal exercise is defined as "anaerobic capacity". The anaerobic work is a workload on the anaerobic threshold, which refers to the application of explosive power, and is a type of physical activity that is manifested by fatigue (Dégoutte, F., et.al., 2003) The concepts of anaerobic and aerobic are in fact interconnected and these concepts are developed through training. Only the aerobic capacity needs to be developed for the development of the anaerobic capacity (Jonathan M, Euan A. A., 1997).

Judo is a way to gain physical strength, coordination and flexibility as well as mental aspects such as self-confidence, balance concentration (Karakoc, 2014-a). Although the organism does not get enough oxygen, oxygen-free working capacity for which energy need continues is called anaerobic power (Dégoutte, F., et.al., 2003) Anaerobic power is defined as the ability to generate power at a certain distance in the shortest possible time (Jonathan M, Euan A.A., 1997). The successful performance of the Judo is very important in anaerobic power. The judoist must be able to maintain a high level of intensity during the competition. At the same time, it is necessary that ideal performance can be maintained during the year. This situation is due to many factors. For this reason, it is important to develop the 
characteristics such as strength, aerobic power, anaerobic power, speed, flexibility, balance and coordination in addition to technical and tactical training with specific judo training.

This study is an experimental study to determine the effects of ten weekly plyometric training on anaerobic power of judokas. The involvement of judokas within the scope of the study is one of the aspects of this study that distinguishes it from other researches related to plyometric training.

\section{Materials and Methods}

30 male judokas were participated in the study and the subjects were divided into two groups as an experimental (15 male age $=21,40 \pm 1,99)$ and control $(15$ male age $=21,53 \pm 1,80)$ groups. A health board report of judokas was taken and a sportsman's license was issued. Research ethics committee approval has been granted.

\section{Training schedule:}

Two groups of volunteers were selected randomly, judo training programme was applied in both groups for 3 days and 90 minutes in a week. Experimental and control group were made warm up exercises for 20 minutes. Both groups continued with the special preparatory period judo training program. After warm up exercises, experimental group judokas were made plyometric training consisting of 15 different movements including 10 legs and 5 hand plyometric drills for 20 minutes, the control group judo training was continued. During the 10-weeks training period, for the first 4 weeks; 5 minutes of training and 15 minutes of rest, between 5 and 7 weeks; 7.5 minutes of training and 12.5 minutes of rest and between 8 and 10 weeks; 10 minutes of training and 10 minutes of rest were applied. Regular judo training was continued for the control group. In each training session, the experimental and control group trained for 90 minutes.

\subsection{Measurements Protocols}

\section{Height:}

Stadiometre (SECA Germany) was used for height measurements with $0.01 \mathrm{~m}$ of accuracy degree in accordance with the measurement techniques (Gordon, 1988).

\section{Anthropometric measurements:}

In order to collect descriptive information in our study, the years of birth of the subjects were asked by themselves and they were determined as years. Measurements of the subjects were taken with an anatomical stance, with sports clothes and without shoes, with a weighing accuracy of $0.1 \mathrm{~kg}$. With a digital height gauge (SECA, Germany) in these weigher, the length dimension was recorded in $\mathrm{cm}$, the body weight was recorded in $\mathrm{kg}$ (Gordon, 1988).

\section{Hand Grip Strength Measurement}

The Holtain brand dynamometer is adjusted according to the subject's hand size, the subject tried to squeeze the dynamometer as much as possible without bending the elbow, the arm is straight and at an angle of 10-15 degrees from the shoulder. The best value was recorded after 4 attempts with both hands. The dynamometer was reset after every attempt, the best performance is taken into evaluation (Tamer, K., 2000).

\section{Leg Strength Measurement}

In this study, "Takei" leg dynamometer measuring leg strength was used. Participants put their foot on the dynamometer table while the knees are in bent condition, hold their arms stretched, hold their knees bent at an angle of $130-140^{\circ}$, hold their back straight and the body bent slightly forward and pulls up the dynamometer grasped by their hands vertically by using their legs at a maximum rate. Relative leg strength = force / body weight (Ozer, 2001).

\section{Measuring Back Force (Back Dynamometer)}

The test measures the strength of the subject's back muscles. Measurements of the subjects were made with a Back - D (Back Strength Dynamometer) back dynamometer, measuring between $0-250 \mathrm{~kg}$. The subjects were measured by using only the back muscles. They took their heads backward, standing on the dynamometer with the $90^{\circ}$ twisted waist and their arms stretched while holding the effort arm. The measurement was repeated twice and the best result was recorded.

\section{Wingate anaerobic power test}

For the Wingate test protocol, a Monark 834 E (Swedish) bicycle ergometer with a scale was used. Before the test, subjects were weighed through an electronic scale. The bicycle saddle height was set separately for each subject. According to the implementation, about 2.50\% (Wp), 5.00\% (W5), 7.50\% (W7.5) and $10.00 \%$ (W10) of the body weight of the subject was put on the scale of the bicycle. He was told that he could start the test by pressing the button that controls the scale whenever he wanted. When the subject felt ready, he pressed the button that controls the scale, dropped the weight on the scale and allowed the pedal to get weight, and from that moment he started pedaling with 
maximal effort for 30 seconds. The subject was spoken orally to motivated so that he could continue his performance with the start of the test. The test was terminated after completion of the period (Bar-Or, O. 1987).

\section{Flexibility Test}

Flexibility measurements of the subjects were made by sitting and reaching test. Test was made with a table with measuring scale of $0-50 \mathrm{~cm}$ on the upper surface, which is $15 \mathrm{~cm}$ outside the surface on which the feet touch and with a length $35 \mathrm{~cm}$, width $45 \mathrm{~cm}$ and height $32 \mathrm{~cm}$, top surface length $55 \mathrm{~cm}$, width $45 \mathrm{~cm}$. Measurements were shown to the subjects before measurements (Tamer, K., 2000). Subjects were sitting barefoot while the knees were at full extension, the feet were open at shoulder width and were based on the test bench while measuring. Without bending the knees, leaning forward with the arms stretched, with the palms facing downwards, leaning forward along the measurement scale, pushing a $30 \mathrm{~cm}$ long ruler forward slowly and without throwing and they were held for 1-2 $\mathrm{sec}$ in the maximum reaching position. The test was repeated twice and the highest result was recorded.

\section{Body Fat Percentage}

Skin fold thickness measurements were performed using a Holtain skin fold caliper applied at $10 \mathrm{~g} / \mathrm{sg} \mathrm{mm}$. which applied $10 \mathrm{~g}$ pressure to $1 \mathrm{~mm}$ at each opening with error $\pm 2 \mathrm{~mm}$. Participants' body fat ratio was measured by the values obtained from the Skinfold measurement from triceps, subsapula, suprailiac and abdominal areas. Yuhasz formula was used for this determination. The measurements were taken from the right side of the participants. In skin fold thickness measurements, the thickness of the subcutaneous fat layer between the index finger and the thumb was set to be light enough to leave muscle tissue. Caliper was held about $1 \mathrm{~cm}$ away from the fingers and the thickness of the subcutaneous fat layer held was read within 2-3 seconds of the caliper display and recorded in millimeters. Test-retest reliability coefficient and total measurement error of skin layer thickness were determined. Yuhasz formula was used to determine the fat percentage of subjects (Zorba, 1995).

\section{Data Analysis}

Statistical analysis was performed using SPSS 16.0 software package. Frequency and percentage distributions, mean and standard deviation, standard errors are used as a Descriptive Statistics. Due to the fact that measurements of the groups showed normality and homogeneous distribution, Paired Samples T-Test was used for the significance between pre-test and post-test measurements. The Independent Samples T-Test was used to analyze the differences between the experimental group and the control group. The error level in this study was taken as $p<0,05$.

\section{Findings}

Table 1. Demographic information for judo athletes from research groups

\begin{tabular}{lll}
\hline \multirow{2}{*}{ Variables } & Experimental group $(\mathrm{N}=15)$ & Control group N=15) \\
& Mean $\pm \mathrm{SD}$ & Mean $\pm \mathrm{SD}$ \\
\hline Age (year) & $21,40 \pm 1,99$ & $21,53 \pm 1,80$ \\
Height $(\mathrm{cm})$ & $176,00 \pm 7,12$ & $177,13 \pm 7,59$ \\
Weight $(\mathrm{kg})$ & $71,26 \pm 9,70$ & $78,73 \pm 17,90$ \\
\hline
\end{tabular}

The average age of Judo athletes in the experimental group was 21,40 $\pm 1,99$ years, 176,00 $\pm 7,12 \mathrm{~cm}$ in height, and $71,26 \pm 9,70 \mathrm{~kg}$ in average body weight. The average age of the Judo athletes in the control group was $21.53 \pm 1.80$ years, $177,13 \pm 7,59 \mathrm{~cm}$ in height and 78,73 $\pm 17,90 \mathrm{~kg}$. in average body weight.

Table 2. Comparison of physical parameters of pre-test and post-test of control group of Judo athletes

\begin{tabular}{lllll}
\hline Veriables & $\begin{array}{l}\text { Pretest (N: 15) } \\
\text { Mean } \pm \text { SD }\end{array}$ & $\begin{array}{l}\text { Post test (N: 15) } \\
\text { Mean } \pm \text { SD }\end{array}$ & T & P \\
\hline Right Hand Grip Strength. $(\mathrm{kg})$ & $46,33 \pm 8,23$ & $46,98 \pm 9,58$ & $-0,527$ & 0,607 \\
Left Hand Grip Strength $(\mathrm{kg})$ & $47,06 \pm 7,33$ & $45,94 \pm 7,61$ & 1,389 & 0,187 \\
Leg strength (kg) & $127,78 \pm 46,30$ & $127,03 \pm 41,46$ & 0,198 & 0,846 \\
Back strength (kg) & $113,86 \pm 27,84$ & $117,60 \pm 26,62$ & $-1,766$ & 0,099 \\
Anaerobic Strength (kg.m/sn) & $9,95 \pm 1,50$ & $9,24 \pm 1,76$ & 2,491 & $\mathbf{0 , 0 2 6} *$ \\
Flexibility (cm) & $19,66 \pm 10,80$ & $18,86 \pm 10,72$ & 0,687 & 0,503 \\
Body Fat Percentage (\%) & $12,85 \pm 5,10$ & $11,44 \pm 4,58$ & 2,433 & $\mathbf{0 , 0 2 9} *$ \\
\hline
\end{tabular}
$* \mathrm{p}<0.05$

When the physical parameters of the control group were examined, the values of anaerobic power and body fat percentage were found significant between pre-test and post-test $(\mathrm{p}<0.05)$. There was no significant difference in right hand grip strength, left hand grip strength, back strength, flexibility, leg strength values ( $p>0.05)$. 
Table 3. Comparison of the pre-test and post-test physical parameters of the experimental group of Judo athletes

\begin{tabular}{lllll}
\hline Veriables & $\begin{array}{l}\text { Pretest (N: 15) } \\
\text { Mean } \pm \text { SD }\end{array}$ & $\begin{array}{l}\text { Post test (N: 15) } \\
\text { Mean } \pm \text { SD }\end{array}$ & T & P \\
\hline Right Hand Grip Strength(kg) & $43,89 \pm 5,25$ & $47,50 \pm 3,61$ & $-3,311$ & $\mathbf{0 , 0 0 5}^{*}$ \\
Left Hand Grip Strength (kg) & $42,13 \pm 4,49$ & $43,41 \pm 4,36$ & $-1,272$ & 0,224 \\
Leg strength (kg) & $117,46 \pm 26,75$ & $125,56 \pm 24,18$ & $-1,564$ & 0,140 \\
Back strength (kg) & $105,03 \pm 17,87$ & $120,40 \pm 20,54$ & $-3,185$ & $\mathbf{0 , 0 0 7}$ \\
Anaerobic Strength (kg.m/sn) & $9,36 \pm 1,37$ & $11,05 \pm 1,81$ & $-3,285$ & $\mathbf{0 , 0 0 5} *$ \\
Flexibility (cm) & $26,73 \pm 7,09$ & $28,60 \pm 7,17$ & $-1,808$ & 0,092 \\
Body Fat Percentage (\%) & $11,06 \pm 3,63$ & $9,03 \pm 2,54$ & 4,426 & $\mathbf{0 , 0 0 1} *$ \\
\hline
\end{tabular}
$* \mathrm{p}<0.05$

When the physical parameters of the experimental group were examined, right hand grip strength, back strength, anaerobic power, body fat percentage values were found significant between the pre and post test $(p<0.05)$. There was no significant difference in left hand grip strength, leg strength and flexibility values $(\mathrm{p}>0.05)$.

Table 4. Comparison of the post test differences of the physical measurement parameters for the experimental and control group of Judo athletes.

\begin{tabular}{|c|c|c|c|c|}
\hline Variables & & Mean \pm SD & $\mathrm{T}$ & $\mathrm{P}$ \\
\hline \multirow{2}{*}{ Right Hand Grip Strength(kg) } & Experimental groups & $-3,60 \pm 4,21$ & \multirow{2}{*}{$-1,803$} & \multirow{2}{*}{0,082} \\
\hline & Control groups & $-0,64 \pm 4,75$ & & \\
\hline \multirow{2}{*}{ Right Hand Grip Strength(kg) } & Experimentel groups & $-1,28 \pm 3,89$ & \multirow{2}{*}{$-1,862$} & \multirow{2}{*}{0,073} \\
\hline & Control groups & $1,12 \pm 3,14$ & & \\
\hline \multirow{2}{*}{ Leg strength $(\mathrm{kg})$} & Experimentel groups & $-8,10 \pm 20,05$ & \multirow{2}{*}{$-1,377$} & \multirow{2}{*}{0,180} \\
\hline & Control groups & $0,75 \pm 14,76$ & & \\
\hline \multirow{2}{*}{ Leg strength (kg) } & Experimentel groups & $-15,36 \pm 18,68$ & \multirow{2}{*}{$-2,208$} & \multirow{2}{*}{$0,036 *$} \\
\hline & Control groups & $-3,73 \pm 8,18$ & & \\
\hline \multirow{2}{*}{ Anaerobic Strength (kg.m/sn) } & Experimentel groups & $0,81 \pm 0,95$ & \multirow{2}{*}{4,033} & \multirow{2}{*}{$0,000 * *$} \\
\hline & Control groups & $-0,71 \pm 1,10$ & & \\
\hline \multirow{2}{*}{ Flexibility (cm) } & Experimentel groups & $-1,86 \pm 3,99$ & \multirow{2}{*}{$-1,714$} & \multirow{2}{*}{0,098} \\
\hline & Control groups & $0,80 \pm 4,50$ & & \\
\hline \multirow{2}{*}{ Body Fat Percentage (\%) } & Experimentel groups & $2,02 \pm 1,77$ & \multirow{2}{*}{0,840} & \multirow{2}{*}{$\mathbf{0 , 0 0 0} * *$} \\
\hline & Control groups & $1,40 \pm 2,24$ & & \\
\hline
\end{tabular}

$* \mathrm{p}<0.05$

When the pre-test and post-test differences of the physical measurement parameters were compared for the experimental and control groups, mean values of back strength, anaerobic power and body fat percentage were found significant $(\mathrm{p}<0.05)$. However, there was no significant difference between right hand grip strength, left hand grip strength, leg strength and flexibility mean values $(\mathrm{P}>0.05)$.

\section{Discussion}

In this study, the effects of ten weekly plyometric exercises on anaerobic power were investigated in judokas. The results of the study were participated in the study by comparing the pre and post test physical parameters of age, height, body weight, right hand and left hand grip strength, leg strength, back strength, anaerobic strength, flexibility and body fat percentage of judo athletes.

The average age of judo athletes in the experimental group was 21,40 \pm 1,99 years and the average age of judo athletes in the control group was $21,53 \pm 1,80$ years. The average height values of the experimental group were $176,00 \pm 7,12$ $\mathrm{cm}$ and the average values of the control group were $177,13 \pm 7,59 \mathrm{~cm}$.

Claessens et al. (1987) were determined that height of the world's top judokas was $1.75 \mathrm{~m}$. the average weight was $79.45 \mathrm{~kg}$ and the average age was 25.3 years (Claessens et al., 1987). Imamoğlu et al. (1999) searched a previous survey on judo male national team and found that the average height was $1.75 \mathrm{~m}$, the average weight was $79.46 \mathrm{~kg}$ and the average age was 20.58 years when we look at the previous research, the average age of the experimental and control groups are close to each other (Imamoğlu et al., 1999).

In this study, the average of pre-test for the experimental group's right hand grip strength was $43.89 \pm 5.25 \mathrm{~kg}$ but the post test average was $47.50 \pm 3.61 \mathrm{~kg}$. The average of pre-test for the left hand grip strength was $42,13 \pm 4,49 \mathrm{~kg}$ but the post test average was $43,41 \pm 4,36 \mathrm{~kg}$. In the control group, the average of pre-test for the right hand grip strength was $46.33 \pm 8.23 \mathrm{~kg}$, but the post test average was $46.98 \pm 9.58 \mathrm{~kg}$., The average of pre-test for the left hand grip strength was $47,06 \pm 7,33$ but the post test average was $45,94 \pm 7,61 \mathrm{~kg}$. 
Tutkun (1996) found a right hand grip strength of Judokas who studied at university was $50.71 \pm 6.01$ and a left hand grip strength was $47.20 \pm 4,12 \mathrm{~kg}$. In another study, a right hand grip strength of Judokas was found $40.70 \pm 9.26 \mathrm{~kg}$ and the left hand grip strength was found $39.37 \pm 9.07 \mathrm{~kg}$ (Karakoc, O., 2016).

Karakoc et al. (2015) found that the average of right hand grip strength of male judokas was $47.55 \pm 7.40$ and the average of left hand grip strength was $46.42 \pm 7.67$. Researches on judokas in the literature have found close values to each other. (Karakoc et al., 2015)

It was mentioned in many studies that the grip strength was very effective in Judo. The grip strength is very important in Judo training because of the intense exercises and struggle to keep the judogi. Especially, the intensity, duration, frequency and extent of the training during the preparation period affect the performance levels of the athletes by the training model (Karakoc, O., 2014-b).

In this study, the average pre-test for the experimental groups' leg strength was $117,46 \pm 26,75 \mathrm{~kg}$, but the post test average was $125,56 \pm 24,18 \mathrm{~kg}$. The average pre-test for the control groups' leg strength was $127,78 \pm 46,30 \mathrm{~kg}$ but the post test average was $127,03 \pm 41,46 \mathrm{~kg}$.

Franchini, E., et al., (2011) found that the average leg strength was $185.1 \pm 25 \mathrm{~kg}$ in international judokas, the leg strength average was $166 \pm 32.7 \mathrm{~kg}$, in national judokas, the average leg strength in recreational judokas was $140 \pm 36$ $\mathrm{kg}$ (Franchini, E.,et.all.2011).

For elite judokas, it is thought that the arm and leg circumferences were wide and therefore also very high in muscle strength (Sacripanti, 1989). Fagerlund and Hakkinen (1991) determined in a study which was about the evaluation of the strength profiles of Finnish judokas and found that the average of leg strength in international judokas was $185.1 \pm 25 \mathrm{~kg}$, and the average of leg strength in national judokas was $166 \pm 327.7 \mathrm{~kg}$, for the recreational judokas, the average leg strength was $140 \pm 36 \mathrm{~kg}$. (Fagerlund and Hakkinen, 1991).

In the study, the average of the back strength for the experimental group's pre test was $105,03 \pm 17,87 \mathrm{~kg}$ but the post test average was $120,40 \pm 20,54 \mathrm{~kg}$. In the control group, the pre test average of the back strength was $113,86 \pm 27,84 \mathrm{~kg}$ but the post test average was $117,60 \pm 26,62 \mathrm{~kg}$.

In the study of determining the relationship between body composition, anaerobic performance and back strength in under elite athletes, the average of back strength values were found $143.16 \pm 27.44$ (Aslan, C. S., et all.2011). In anaother study that was about the effects of plyometric training, in the control group the pre test average of back strength was $109,37 \pm 12,50 \mathrm{~kg}$ but the post test average was $111,25 \pm 12,77 \mathrm{~kg}$. In the experimental group, the pre-test average of the back strength was $115,25 \pm 11,9 \mathrm{~kg}$ and the post test average was $126,08 \pm 12,17 \mathrm{~kg}$ (Ates, M., \& Atesoğlu, U., 2007).

Celenk, C., \& Cumraligil, B. (2005) compared some physical and physiological characteristics of team athletes and individual athletes, and determined the average back strength in judokas was 144,85 $\pm 12,85$ (Celenk, C., \& Cumraligil, B. 2005).

Sbriccoli et al., (2007) were identified that the muscle power was at a high level and the aerobic capacities were quite good on the Italian olympic judokas. (Sbriccoli et al., 2007). They also concluded that the upper extremity and arms are quite good conditionally in short-duration high-intensity charges with the characteristic feature of judo.

Plyometric studies have been combined to improve motion speed and force-power production. Plyometric training is now being used in many sport branches that require rapid force (Takahashi, R., 1992).

Ates M. and Atesoğlu (2007), found that plyometric training positively affects upper and lower extremity strength values of athletes.

Rubley et al., (2011), were identified that plyometric exercises were improved the lower extremity explosive force levels on athletes.

Plyometric training is at the forefront of the training models that are commonly used to support strength development and increase strength in a short period of time. In addition, plyometric training contributes to the development of physical performance (Piirainen, J. M., et al., 2014)

In this study, the average of the flexibility for the experimental group's pre test was $26.73 \pm 7,09 \mathrm{~cm}$, and the average of the post-test was $28,60 \pm 7,17 \mathrm{~cm}$. The average of the flexibility for the control group's pre test was $19.66 \pm 10.80 \mathrm{~cm}$, and the average of the post-test was $18.86 \pm 10.72 \mathrm{~cm}$.

Krstulovic S. (2012) were grouped judo athletes as light, middle and heavyweight. In Judo performance tests, the average of flexibility test in lightweight athletes was $4.79 \pm 1.23 \mathrm{~cm}$, the average of the flexibility test in the middle-weight athletes was $5.28 \pm 0.95 \mathrm{~cm}$. and the average of the flexibility test in the heavyweight athletes was $5.41 \pm 0.98 \mathrm{~cm}$.

Flexibility is the ability of moving joints or joint series at wide angles. This is why flexibility is not only important for 
sporting success and performance, but also for prevention from injuries (Dogan A., Zorba E., 1991).

Judo also needs a high level of flexibility in order for a lot of techniques to be done in wide range of angles and for the movement to be done properly.

In this study; according to the body fat percentage and standard deviation values of the subjects, the pre-test averages of the experimental group were found $11,06 \pm 3,63 \%$ and the post test averages were found $9,03 \pm 2,54 \%$. The pre-test averages of the control group were $12,85 \pm 5,10 \%$ and the post test results were $11,44 \pm 4,58 \%$.

Farmosi, I. (1980) studied some motor performances of male judokas, the average of body fat percentage for judo team of Hungary were found $8.9 \pm 0.8 \%$ for athletes under $70 \mathrm{~kg}$ and $14.0 \pm 7.3 \%$ for athletes over $70 \mathrm{~kg}$.

In the study of the physiological characteristics of elite judo athletes, Callister et al. (1991) found body fat percentage of the American senior judo group as $8.3 \pm 1.0 \%$.

In another study, after 8 weeks of submaximal aerobic exercise in young male subjects, body fat, percentage of body fat, body fat and lean body mass were reduced .(Daglioglu O, 2013).

Rates of the body fat percentage in the studies we have given in the above literature is lower than the rates of the body fat percentage of this study. According to studies in the literature it is thought that the reason for this, the sporting age of the athletes is older and occurs more elite groups.

Muscle strength and strength in individual and team sports is determinant of successful performance. Coaches emphasize plyometric training one of the optimal training methods to improve strength, power and competition performance ( Little, A.D., et.,1996).

\section{Conclusion}

In many studies in the literature, it is important that the development of motoric features with plyometric exercises is parallel to this study on judoist. As a result of the plyometric training, when the pre-test and post-test differences of the physical measurement parameters were compared for the experimental and control groups, average values of back strength, anaerobic power and body fat percentage were found significant $(\mathrm{p}<0.05)$.

In conclusion, it can be concluded that regular plyometric training improves the performances of judokas, and practice of plyometric training in addition to judo training is beneficial for sportive performance.

\section{Acknowledgements}

This is a part of Ahmet Uzun's master thesis. We thank our department of Physical Education and Sport in University of Gaziantep for their support to our study.

\section{References}

Aslan, C. S., Buyukdere, C., Koklu, Y., Ozkan, A., \& Ozdemir, F. N. S. (2011). Elit Altı Sporcularda Vücut Kompozisyonu, Anaerobik Performans Ve Surt Kuvveti Arasındaki İliskinin Belirlenmesi. Uluslararası İnsan Bilimleri Dergisi, 8, 1612-1628.

Ates, M., \& Atesoglu, U. (2007). Pliometrik Antrenmanın 16-18 Yas Grubu Erkek Futbolcuların Üst ve Alt Ekstremite Kuvvet Parametreleri Üzerine Etkisi.

Bar-Or, O. (1987). The Wingate Anaerobic Test An Update On Methodology, Reliability And Validity. Sports Medicine, 4(6), 381-394. https://doi.org/10.2165/00007256-198704060-00001

Callister, R. (1991). Physiological Characteristics Of Elite Judo Athletes. International Journal Of Sports Medicine, 12(02), 196-203. https://doi.org/10.1055/s-2007-1024667

Celenk, C., \& Cumralıgil, B. (2005). Takım Sporcuları İle Ferdi Sporcuların Bazı Fiziksel Ve Fizyolojik Ozelliklerinin Karsilastır1masi. Journal Of Physical Education And Sport Sciences, 7(3).

Claessens, A., Bennen, G., Wellens, R., \& Geldof, G. (1987). Somatotype And Bady Structure Of World Top Judo İsts, J. Sports Med., 27, 105-112.

Daglioglu, O. (2013). The effect of 8-week submaximal aerobic exercise on cardiovascular parameters and Body composition in young men. International Journal of Academic Research Part A, 5(4), 210-216. https://doi.org/10.7813/2075-4124.2013/5-4/A.29

Dégoutte, F., Jouanel, P., \& F1laıre, E. (2003). Energy Demands During A Judo Match And Recovery. Br. J. Sports Med., 37(3), 245-249. https://doi.org/10.1136/bjsm.37.3.245

Dogan, A., \& Zorba, E. (1991). Esnekliğin Gelistirilmesinde Kullanılan Farklı Esnetme Tekniklerinin Etkinliği, H. Eğitim Fakültesi Spor Bilimleri Dergisi, 2, 41-48. 
Fagerlund, R., \& Hakkınen, H. (1991). Strength Profile Of Finnish Judoists-Measurement And Evaluation. Biology Of Sport, $8(03), 143-149$.

Farmosi, I. (1980). Body-Composition, Somatotype And Some Motor Performance Of Judoists. The Journal Of Sports Medicine And Physical Fitness, 20(4), 431.

Franchini, E., Del Vecchio, F. B., Matsushigue, K. A., \& Artioli, G. G. (2011). Physiological Profiles Of Elite Judo Athletes. Sports Medicine, 4l(2), 147-166. https://doi.org/10.2165/11538580-000000000-00000

Gordon, S. (1988). Decision Styles And Coaching Effectiveness In University Soccer. Canadian Journal Of Sport Sciences.

Imamoğlu, O., Kishah, N. F., Cebi, M., \& Imamoğlu, H. (1999). Türk Judo Erkek Milli Takımında Vücut Kompozisyonu Parametrelerin İncelenmesi, Erzurum Atatürk Üniversitesi Beden Eğitimi ve Spor Yüksekokulu Dergisi,C. I, S. I, Sh. 12-18.

Jonathan, M., \& Euan, A. (1997). Perspective On Exercise, Lactate, And The Anaerobic Threshold. Chest P, 111, 787-795.

Kalyon, T. A. (1990). Spor Hekimliği, Gata Basımevi, Ankara.

Karakoc, O. (2014a). Judo Oğreniyorum. Bagırgan Yayınevi.Ankara

Karakoc, O. (2014b). İsitme Engelli Judocularda Sekiz Haftalık Denge Ve Koordinasyon Antrenmanlarının Performans Üzerine Etkileri, Furat Ü.B.E.S.A.B.D. Doktora Tezi. Elazı̆g.

Karakoc, O. (2016). Muscle Strength And Flexibility Without And With Visual Impairments Judoka's. International Education Studies, 9(5). https://doi.org/10.5539/ies.v9n5p12

Karakoc, O. et. all. (2015). Spor ve Performans Arastirmaları Dergisi Journal of Sports and Performance Researches. http://dergipark.ulakbim.gov.tr/omuspd58 Cilt

Krstulovic, S. (2012). Predictors Of Judo Performance İn Male Athletes University Of Sarajevo, Faculty Of Sport \& Physical Education Homo Sporticus Issue, Croatia.

Little, A. D., Wilson, G. J., \& Ostrowski, K. L. (1996). Enhancing Performance: Maximal Power Versus Weight And Plyometrics Training, Journal of Strength And Conditioning Research, 10, 173-179. https://doi.org/10.1519/00124278-199608000-00008

Ozer, K. (2001). Fiziksel Uygunluk. Ankara: Nobel Yayınları.

Piirainen, J. M., Cronin, N. J., Avela, J., \& Linnamo, V. (2014). Effects Of Plyometric And Pneumatic Explosive Strength Training On Neuromuscular Function And Dynamic Balance Controlin 60-70 Year Old Males. Journal Of Electromyography And Kinesiology, 24, 246-252. https://doi.org/10.1016/j.jelekin.2014.01.010

Rubley, M. D., Haase, A. C., Holcomb, W. R., Girouard, T. J., \& Tandy, R. D. (2011). The Effect Of Plyometric Training On Power And Kicking Distance İn Female Adolescent Soccer Players. The Journal Of Strength \& Conditioning Research, 25(1), 129-134. https://doi.org/10.1519/JSC.0b013e3181b94a3d

Sacripanti, A. (1989). Biomeccanica Del Judo. Mediterranee.

Sbriccoli, P., Bazzucchi, I., Di Mario, A., Marzattinocci, G., \& Felici, F. (2007). Assessment Of Maximal Cardiorespiratory Performance And Muscle Power İn The Italian Olympic Judoka. The Journal Of Strength \& Conditioning Research, 21(3), 738-744.

Takahashi, R. (1992). Power Training For Judo: Plyometric Training With Medicine Balls, Natl. Strength Cond. Assoc. J. 14(2), 66-71. https://doi.org/10.1519/0744-0049(1992)014<0066:PTFJPT>2.3.CO;2

Tamer, K. (2000). Sporda Fiziksel-Fizyolojik Performansın Ölçülmesi Ve Değerlendirilmesi. Bağırgan Yayım Evi, Ankara, 36, $8-49$.

Tutkun, E. (1996). Hentbol, Voleybol, Futbol, Güres, Judo Okul Turnuvalarında Yer Alan Üniversite Öğrencilerinin Antropometrik Yapıları İle Moratsa! Test Ölçümlerinin İncelenmesi, Yüksek Lisans Tezi, Samsun.

Zorba, E., \& Ziyagil, M. A. (1995). Vücut Kompozisyonu ve Ölçüm Metodları. Gen Matbaacılık Reklamcılık Ltd. Sti. Trabzon.

\section{Copyrights}

Copyright for this article is retained by the author(s), with first publication rights granted to the journal.

This is an open-access article distributed under the terms and conditions of the Creative Commons Attribution license which permits unrestricted use, distribution, and reproduction in any medium, provided the original work is properly cited. 